\title{
A new Neotropical species of spot-thoraxed Drosophila (Diptera, Drosophilidae)
}

\author{
Vilma Ratcov ${ }^{1} \&$ Carlos R. Vilela ${ }^{2}$
}

\begin{abstract}
${ }^{1}$ Universidade Braz Cubas, Av. Francisco Rodrigues Filho 1233, 08773-380, Mogi das Cruzes-SP, Brazil. vilmaratcov@uol.com.br ${ }^{2}$ Departamento de Genética e Biologia Evolutiva, Instituto de Biociências, Universidade de São Paulo, Caixa Postal 11461, 05422-970, São Paulo-SP, Brazil. crvilela@ib.usp.br
\end{abstract}

\begin{abstract}
A new Neotropical species of spot-thoraxed Drosophila (Diptera, Drosophilidae). Drosophila pauliceia sp. nov., a spot-thoraxed species closely related to Drosophila boraceia Vilela \& Val, 2004, is described from flies collected in an urban remnant of the montane Atlantic Forest located at the Cidade Universitária "Armando de Salles Oliveira", São Paulo city, state of São Paulo, Brazil. The two forest-dwelling species can be externally distinguished mainly by having a different pattern of thoracic spots. A new group of spotted flies (peruensis group) is proposed to include them, in addition to Drosophila peruensis Wheeler, 1959, from Urubamba River, Peru, and Drosophila atalaia Vilela \& Sene, 1982, from Brazil and Argentina. To facilitate comparisons, illustrations of the male and female terminalia of the new species and of some unpublished views of those of D. atalaia are included. Additionally, a new group of unspotted species (named caponei group) is proposed to include Drosophila caponei Pavan \& Cunha, 1947 and D. neochracea Wheeler, 1959, both previously considered to be related to D. atalaia.
\end{abstract}

KEYWORDS. Atlantic forest; caponei group; peruensis group; male terminalia; taxonomy.

RESUMO. Uma nova espécie Neotropical de Drosophila com tórax pintado (Diptera, Drosophilidae). Drosophila pauliceia sp. nov., espécie com tórax pintado e muito semelhante à Drosophila boraceia Vilela \& Val, 2004, é descrita a partir de exemplares procedentes de um fragmento urbano da Mata Atlântica de planalto, localizado na reserva da Cidade Universitária "Armando de Salles Oliveira", cidade de São Paulo, estado de São Paulo, Brasil. As duas espécies podem ser separadas principalmente com base no padrão das pintas do tórax e, juntamente com Drosophila peruensis Wheeler, 1959 e Drosophila atalaia Vilela \& Sene, 1982, são incluídas em um novo grupo proposto no presente artigo sob o nome peruensis. Além das ilustrações detalhadas das terminálias masculina e feminina da nova espécie, desenhos inéditos dessas estruturas foram preparados também para Drosophila atalaia. Adicionalmente é proposto o grupo caponei que inclui D. caponei Pavan \& Cunha, 1947 e D. neochracea Wheeler, 1959, duas espécies com tórax não pintado embora previamente consideradas próximas à $D$. atalaia.

PALAVRAS-CHAVE. grupo caponei; grupo peruensis; Mata Atlântica; taxonomia; terminália masculina.

The presence of dark spots at the base of each thoracic seta readily distinguish the species belonging to two large and apparently not closely related groups of Neotropical species of Drosophila, namely the annulimana and the repleta groups, from those belonging to other groups. This feature which seems to have also independently occurred in several rather unrelated groups belonging to different genera of Drosophilidae is most probably a homoplasy. Thus, such a state of character can be misleading whenever used as the sole indication of close relationships. A survey of this clearcut condition within the Drosophilidae has recently been summarized by Vilela \& Val (2004) in a paper where they described one spotted and then ungrouped South-American species named Drosophila boraceia.

The discovery of an additional undescribed species closely related to Drosophila boraceia, and the realization of their similarity to Drosophila atalaia Vilela \& Sene, 1982 and to Drosophila peruensis Wheeler, 1959 (currently included in the guarani group) prompted the present paper and suggested the existence of one previously unrecognized Neotropical group of spot-thoraxed species, neither closely related to the annulimana group nor to the repleta group. This new group of four species, hereafter named peruensis group, is proposed following the description of the new species and supplementary descriptions of the male and female terminalia of Drosophila atalaia. Additionally, a second new group named caponei group is proposed to include two species previously considered to be related to Drosophila atalaia but bearing unique features on their male terminalia.

\section{MATERIAL AND METHODS}

One male collected in June 1996 and one female collected in July 1997, plus her offspring [one pupa within puparium and a male imago] yielded in the laboratory in banana-agar medium, were used to describe the new species. The wildcaught couple was collected with an entomological net over banana-baited traps set in an urban fragment of the montane Atlantic forest of southeastern Brazil and are detailed under the description. This fragment is represented by the forest reserve of the Cidade Universitária "Armando de Salles Oliveira", São Paulo city, state of São Paulo, Brazil. The four specimens are housed in the Museu de Zoologia da Universidade de São Paulo, São Paulo, Brazil (MZSP). 


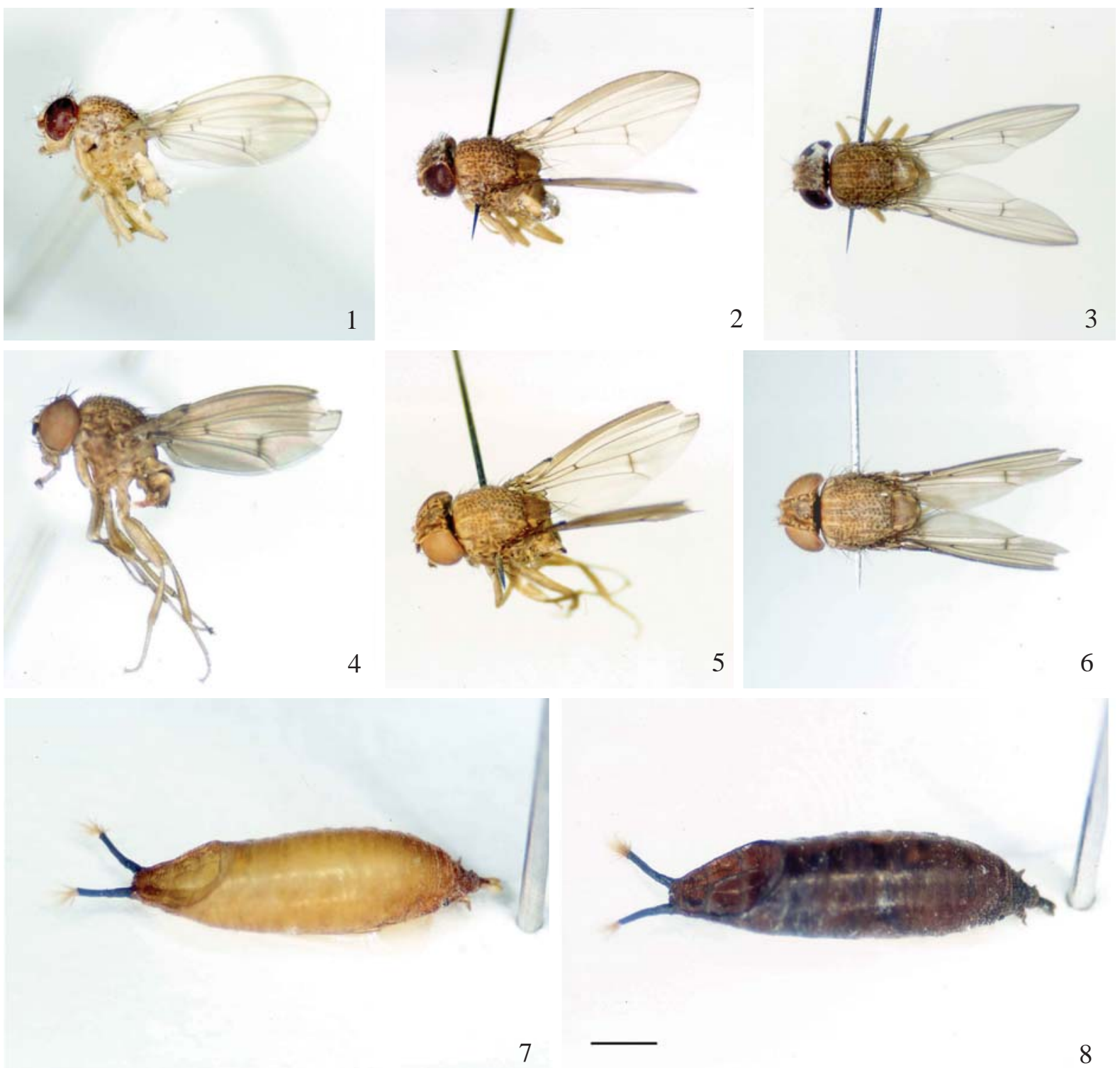

Figs. 1 - 8. Photomicrographs of imagines and puparia of Drosophila pauliceia sp. nov.. 1-3, male holotype: 1, left lateral view, 2, left laterodorsal view, 3, dorsal view; 4-7, male paratype: 4, left lateral view, 5, left laterodorsal view, 6, dorsal view, 7, empty puparium, left laterodorsal view; 8, paratype of unknown sex within puparium, left laterodorsal view. Scale bar $=1 \mathrm{~mm}$.

Label data attached to each type specimen are cited in full with a comma indicating a line change, and a slash indicating a label change. Our own notes or interpretations are included in brackets.

For morphological terminology, measurements, indices, preparations of microscope slides as well as illustrations see Vilela \& Bächli (2000) and Bächli et al. (2004). Whenever in the same plate, all line drawings were drawn to the same scale, and all photomicrographs were taken and enlarged to the same magnification.

To improve the original description of the terminalia of Drosophila atalaia, two of its paratypes (1 male [previously dissected], and 1 female [dissected in the present study]), which are deposited in the Museu de Zoologia, Universidade de São Paulo, were also analyzed. Illustrations of parts of their terminalia are also included.

\section{Drosophila pauliceia sp. nov.}

(Figs. 1 -19, 31-34)

Material examined ( 2 males, 1 female, 1 pupa within puparium, deposited in MZSP). Holotype male [wild-caught, coded I45, dissected] labelled: "Brasil - SP - São Paulo, Reserva da, Cidade Universitária, 27.VI.1996, Ratcov \& Vilela coll. / Drosophila pauliceia [male symbol] Ratcov \& Vilela / terminália ilustrada [illustrated terminalia] / espécimen fotografado [photographed specimen] / HOLOTYPE / [microvial with terminalia]". Paratypes $=1$ wild-caught female $[$ coded I72F94, 
dissected] plus its offspring: 1 male [dissected, photographed, empty puparium glued to a point] and 1 pupa [sex unknown] within puparium [photographed] bred in the laboratory in banana-agar medium: same data as holotype except for collection date $\left(\right.$ wild-caught female $=31$.VII.1997, emerged $F_{1}$ generation male $=8$-15.IX.1997).

Type locality. Cidade Universitária "Armando de Salles Oliveira”, São Paulo, state of São Paulo, Brazil.

Diagnosis. Body color mainly light brown; frons dark brown, medially and laterally light brown pollinose; antennae and palpi dark brown; scutum brown with setae and setulae emerging from dark brown spots; $\mathrm{h}$ index 0.77 - 1; mid katepisternal about $26-40 \%$ of the anterior one; two large prescutellars; wings light brown, anteriorly slightly darker, crossveins slightly clouded, lappet dark brown; C index 3.42 4 ; hb index $0.39-0.44 ; 5 \mathrm{x}$ index $1.1-1.3$.

\section{Description.}

Head brown. Frons dark brown, dull, frontal length 0.49 $(0.46-0.51) \mathrm{mm}$; frontal index $=0.92(0.90-0.95)$, top to bottom width ratio $=1.34$ (1.26-1.39). Frontal triangle light brown pollinose, about $91 \%$ of frontal length; ocellar triangle greyish brown, about 35\% of frontal length. Mid orbital somewhat outside of anterior one, or 3 to or $1=100 \%$ of that to inner vertical; or $1 /$ or 3 ratio $=1$; or 2 or 1 ratio $=0.50-0.56$; $\operatorname{poc} 37 \%$ $-52 \%$, oc $57 \%-65 \%$ of frontal length; vibrissal index $=0.7$ 0.8 ; vt index $=1.14(1.00-1.25)$, facial carina light brown, noselike, slightly sulcate. Gena light brown, cheek index about $10-12$. Eye index $=1.12-1.26$. Pedicel laterally light brown, medially darker, first flagellomere blackish brown; length to width ratio 1.12 - 1.40. Arista with 4-5 dorsal, 2 ventral and 6-7 tiny inner branches, plus long terminal fork. Proboscis brown.

Thorax light brown, each seta and setula arising from a dark brown spot at base; length 1.51 (female) - 1.55 (1.46 - 1.63) (male) $\mathrm{mm}$. Scutum pollinose, brownish-yellow, 8 rows of acrostichal setae. $\mathrm{h}$ index $=0.88(0.77-1.00)$. Transverse distance of dorsocentral setae $257 \%$ of longitudinal distance; dc index $=0.63(0.52-0.82)$; two large prescutellars. Scutellum laterally light brown, medially darker, scutellars emerging from slightly darker areas; distance between apical scutellar setae about $85 \%$ of that of apical to basal one, basal setae slightly divergent; scut index $=0.80(0.79-0.81)$. Halteres brown. Pleura brown, sterno index $=0.79(0.75-0.86)$, mid katepisternal seta about $26-40 \%$ of the anterior one. Legs light brown.

Wing (Figs. 1-6) light brown, anteriorly slightly darker, crossveins slightly clouded, lappet dark brown; length 3.00 $(2.95-3.05)$ (male) -3.07 (female) $\mathrm{mm}$; length to width ratio $=$ $2.13(2.02$ - 2.25). Indices: $\mathrm{C}=3.79(3.42-4.00), \mathrm{ac}=1.94(1.83$ $2.00), \mathrm{hb}=0.41(0.39-0.44), 4 \mathrm{C}=0.65(0.61-0.71), 4 \mathrm{v}=1.47$ $(1.39-1.53), 5 \mathrm{x}=1.18(1.10-1.30), \mathrm{M}=0.43(0.39-0.47)$, prox. $\mathrm{x}$ $=0.60(0.59-0.61)$.

Abdomen light brown, tergites with a broad, brownish marginal band which is medially interrupted. Male sternites 3 and 4 almost as wide as long, sternite 5 narrowed, noticeably wider $(2.8 \mathrm{x})$ than long.

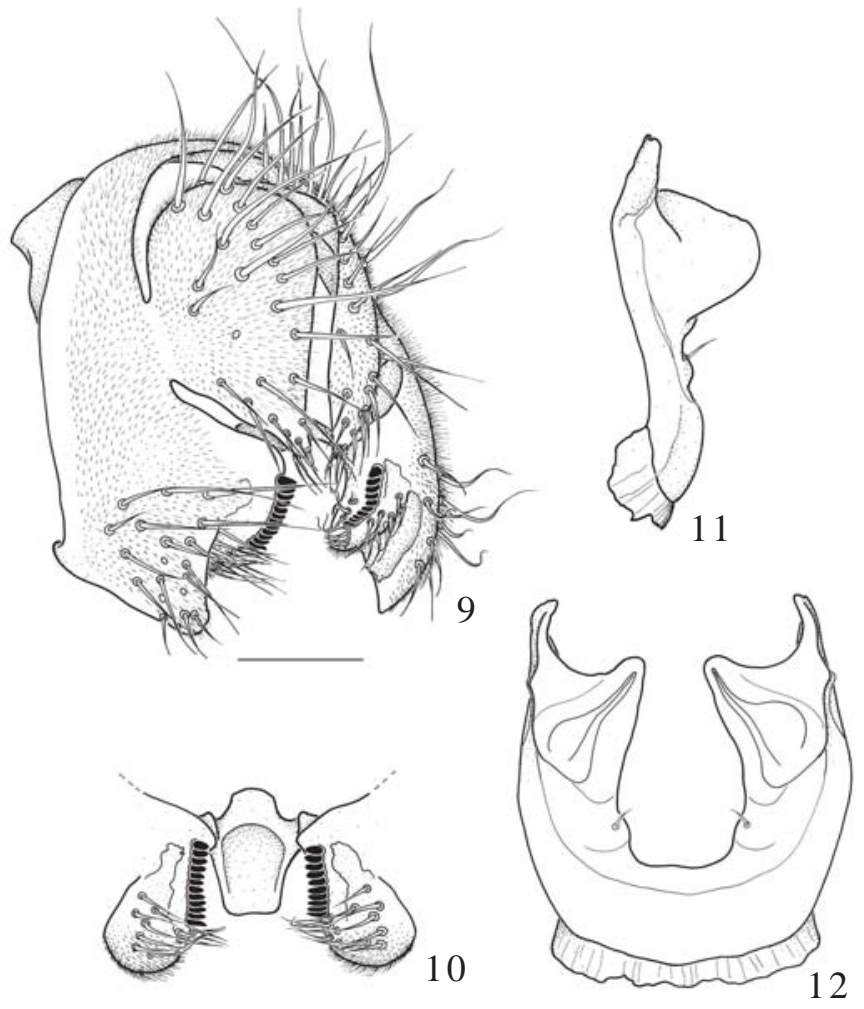

Figs. 9 - 12. Drosophila pauliceia sp. nov., holotype. 9, epandrium+cerci, surstyli and decasternum, oblique posterior view; 10, surstyli and decasternum, posterior view; 11, hypandrium+gonopods, left lateral view; 12, idem, posterior view. Scale bar $=0.1 \mathrm{~mm}$.

Male terminalia (Figs. 9-17). Epandrium mostly microtrichose, with 20 lower, and no upper setae; ventroanteriorly protruding anterad; ventral lobe mostly microtrichose, square-shaped, mostly covering surstylus. Cerci anteriorly fused medially to epandrium, mostly microtrichose and devoid of ventral lobe, although ventromedially each plate is slightly projected downwards. Surstylus mostly fused to epandrium, partially microtrichose, bearing ca. 11 cone-shaped prensisetae, 12 outer and 4 inner setae. Decasternum longer than wide, as in Fig. 10. Hypandrium (Figs. 11, 12) square-shaped, shorter than epandrium; posterior hypandrial process absent; dorsal arch absent; gonopod fused to hypandrium (fusion line apparent), linked to paraphysis by membranous tissue, ventrally straight and dorsally protruded backwards in lateral view, bearing one tiny seta near the anterior inner margin; posterior margin concave. Aedeagus fused to aedeagal apodeme (Figs. 13-17, 31-34), dorsally convex, rounded in profile at tip, laterally covered with minute scales preceding a pair of long, ventromedian, directed frontwards pointed spurs, which reach the paraphysis; dorsal cleft reduced to a small opening adjacent to the fusion aedeagus-aedeagal apodeme. Aedeagal apodeme shorter than aedeagus, posteriorly expanded, laterally flattened. Ventral rod entirely fused to aedeagal apodeme. Paraphysis square-shaped, not microtrichose, distally with 1 small seta, connected to distal 

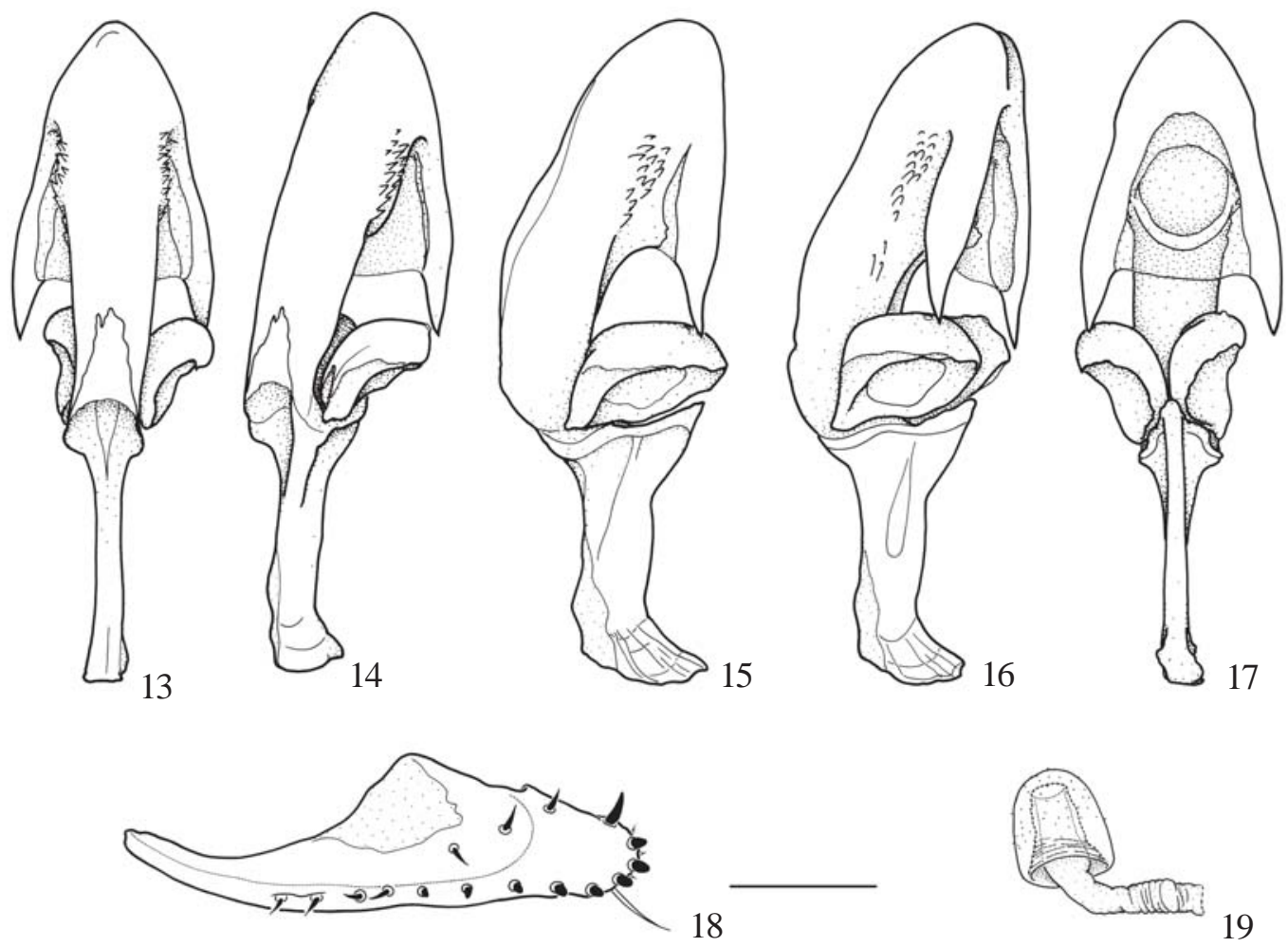

19

Figs. 13 -19. Drosophila pauliceia sp. nov.: 13-17, male holotype, aedeagus+aedeagal apodeme and paraphyses, several views from dorsal through ventral; 18, 19 female paratype, 18, left oviscapt valve, outer lateral view, 19, inner capsule of spermatheca and distal region of spermathecal duct, lateral view. Scale bar $=0.1 \mathrm{~mm}$.

margin of aedeagal apodeme by membranous tissue.

Female terminalia (Figs. 18, 19). Oviscapt valve apically rounded with ca. 12 marginal mostly peg-like ovisensilla (four most anteriorly ones trichoid-like) and ca. 4 discal trichoid-like (three most anteriorly ones sharper and thinner) ovisensilla (Fig. 18). Spermathecal capsule (Fig. 19) weakly sclerotized, dome-shaped, mostly warty; basal introvert around $4 / 5$ the capsule length, annulated at proximal 1/3; devoid of apical introvert.

Puparia (Figs. 7, 8) . Remarkably long (ca. $5.6 \mathrm{~mm}$, without spiracles) regarding imago's body length (ca. $4 \mathrm{~mm}$ without wings); light brown; horn index about 3.8; stalk of anterior spiracle conspicuously black, with about 22 light brownish yellow tracheal branches.

Distribution. So far known only from the type locality (city of São Paulo, state of São Paulo, Brazil).

Etymology. The epithet pauliceia is a noun in apposition and an allusion to the type locality (city of São Paulo) as it was referred to in Mario de Andrade's poetry-book "Paulicéia Desvairada" [Hallucinated São Paulo], which is considered to be a mark in the cultural movement of the 1920's known as Modernism.

Relationship. It belongs to the Drosophila peruensis species group (new group) of the subgenus Drosophila. It is extremely similar to Drosophila boraceia from which it differs mainly by having the thoracic spots not fused (in D. boraceia, confluent spots form 4 longitudinal stripes), in addition to a distinct aedeagus, which laterally is covered with a patch of tiny scales adjacent to the pair of subapical spurs (aedeagus devoid of tiny scales in $D$. boraceia).

\section{Drosophila atalaia Vilela \& Sene, 1982}

(Figs. 20-30, 35, 36)

Material examined (2 paratypes: 1 male and 1 female, deposited in MZSP). Male paratype [previously dissected] labelled: 'Brasil - ES, Vitoria [Ilha do Boi], 20¹8'S, 40¹7'W, E. Stange col., x.1977 / PARATIPO, Drosophila atalaia, [male symbol]. Female paratype [dissected] labelled: "Brasil - RJ, Arraial do Cabo, Atalaia, $22^{\circ} 58^{\prime}$ S, $42^{\circ} 02^{\prime} \mathrm{W}$, Baimai \& Vilela [coll.], 25-26.X.1981 / PARATIPO, Drosophila atalaia, [female symbol].

Supplementary descriptions of male and female terminalia:

Male. Surstylus (Fig. 20) bearing sharply pointed prensisetae. Decasternum wider than long, as in Fig. 20. Hypandrium (Figs. 21-23) bearing a spurious dorsal arch, and completely fused (fusion line apparent) to gonopods, which are dorsally projected backwards; each gonopod anteriorly bearing one tiny setulae; posterior hypandrial process absent. Aedeagus (Figs. 24-28, 35, 36) fused to both the aedeagal apodeme and the ventral rod; bearing a membranous strip between the ventrodistal spurs and the minute lateral scales.

Female. Oviscapt valve (Fig. 29) apically rounded with 10 

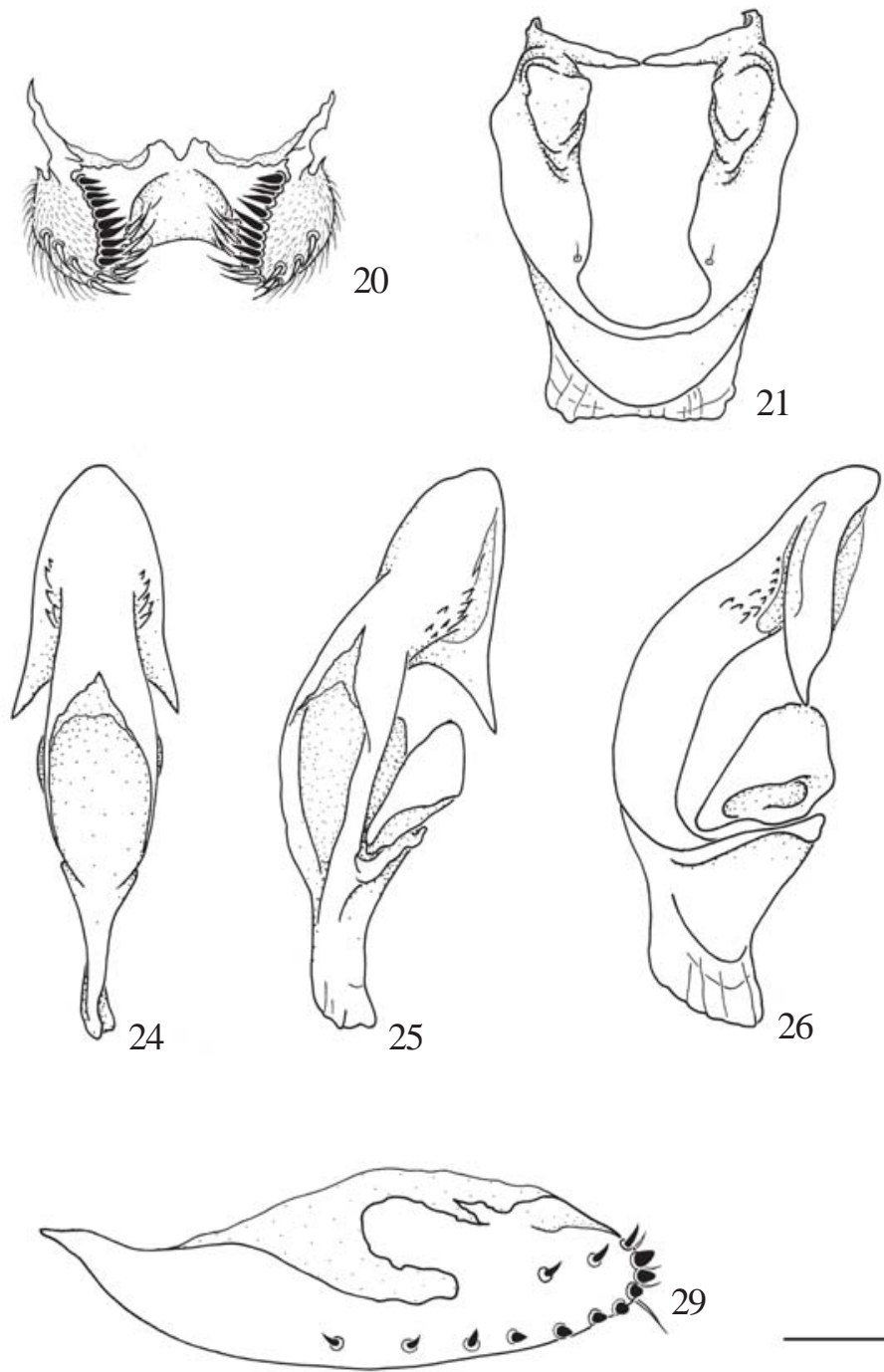

Figs. 20 - 30. Drosophila atalaia: 20-28, male paratype (from Vitória, ES), 29, 30, female paratype (from Arraial do Cabo, RJ). 20, surstylus+decasternum, posterior view, 21-23, hypandrium+gonopods, posterior, lateroposterior and left lateral views, 24-28, aedeagus+aedeagal apodeme and paraphyses, several views from dorsal through ventral; 29, 30, female paratype, 29, left oviscapt valve, outer lateral view, 30, inner capsule of spermatheca and distal region of spermathecal duct, lateral view. Scale bar $=0.1 \mathrm{~mm}$.

marginal peg-like ovisensilla (except two most anteriorly ones, trichoid-like) and 3 discal trichoid-like ovisensilla. Spermathecal capsule (Fig. 30) distally warty, proximally annulated and devoid of apical introvert; basal introvert around $3 / 5$ the capsule length; spermathecal duct distally remarkably dilated, bearing a subterminal bulbous, just where it enters the capsule.

Comments on the related species.

Drosophila peruensis Wheeler, 1959 was originally described by Duda (as Drosophila maculipennis) in 1927 from a single Peruvian female fly collected alongside the Urubamba River (exact locality unknown) in 1903. Probably due to its spotted thorax it was tentatively ascribed by Sturtevant (1942: 31 ) to the repleta group. In the long standing search for a male specimen that could be associated with the cited female specimen, two species of spot-thoraxed Drosophila with wings
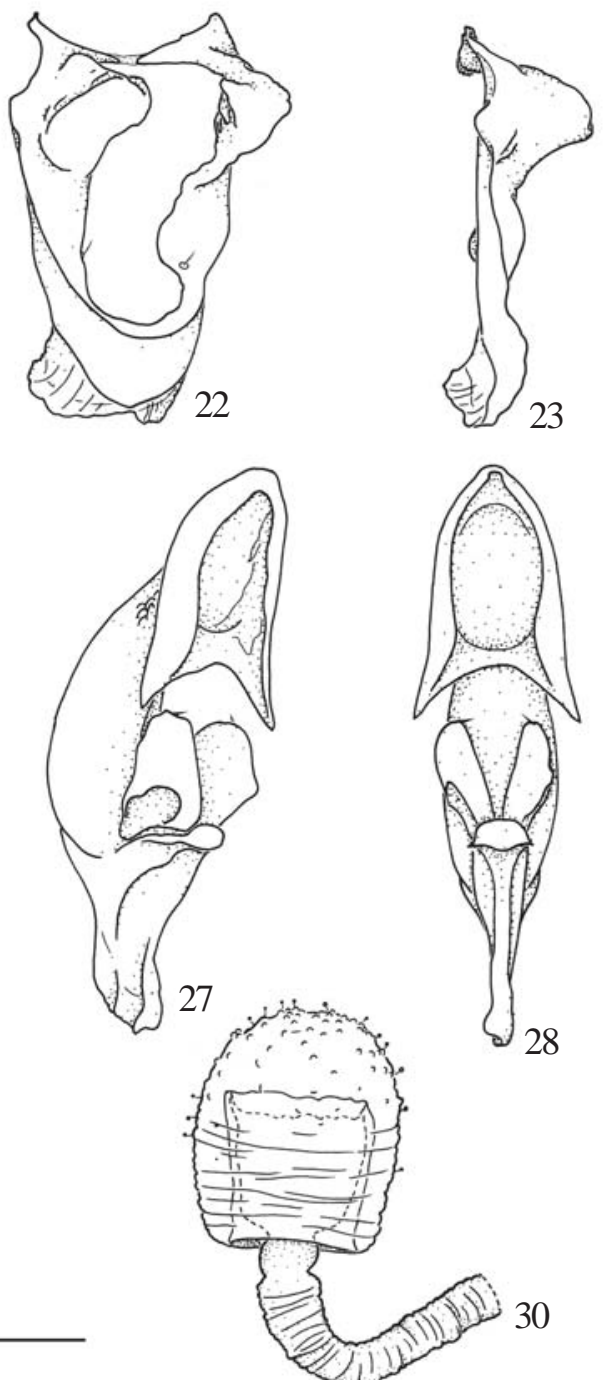

bearing the two main crossveins and tips of $R_{2+3}$ and $R_{4+5}$ clouded have been successively misidentified by one of us (CRV) as Drosophila peruensis (Vilela et al., 1980; Vilela \& Pereira, 1985; Vilela \& Pereira, 1993). They are as follows: Drosophila tucumana Vilela \& Pereira, 1985, from north western Argentina and D. urubamba Vilela \& Pereira, 1993, from eastern Peru. Both their male and female terminalia clearly relate them to the species of Drosophila belonging to the guarani group. Accordingly, Drosophila peruensis was transferred from the repleta to the guarani species group by Vilela (1983:102). At that time, mainly because of sharing spotted thorax, and wings with main crossveins and tips of $R_{2+3}$ and $\mathrm{R}_{4+5}$ clouded, it was believed the three species were closely related. However, a reanalysis of the female terminalia (oviscapt valves and spermathecae) of the first two species has shown they are indeed quite similar, however they are remarkably 

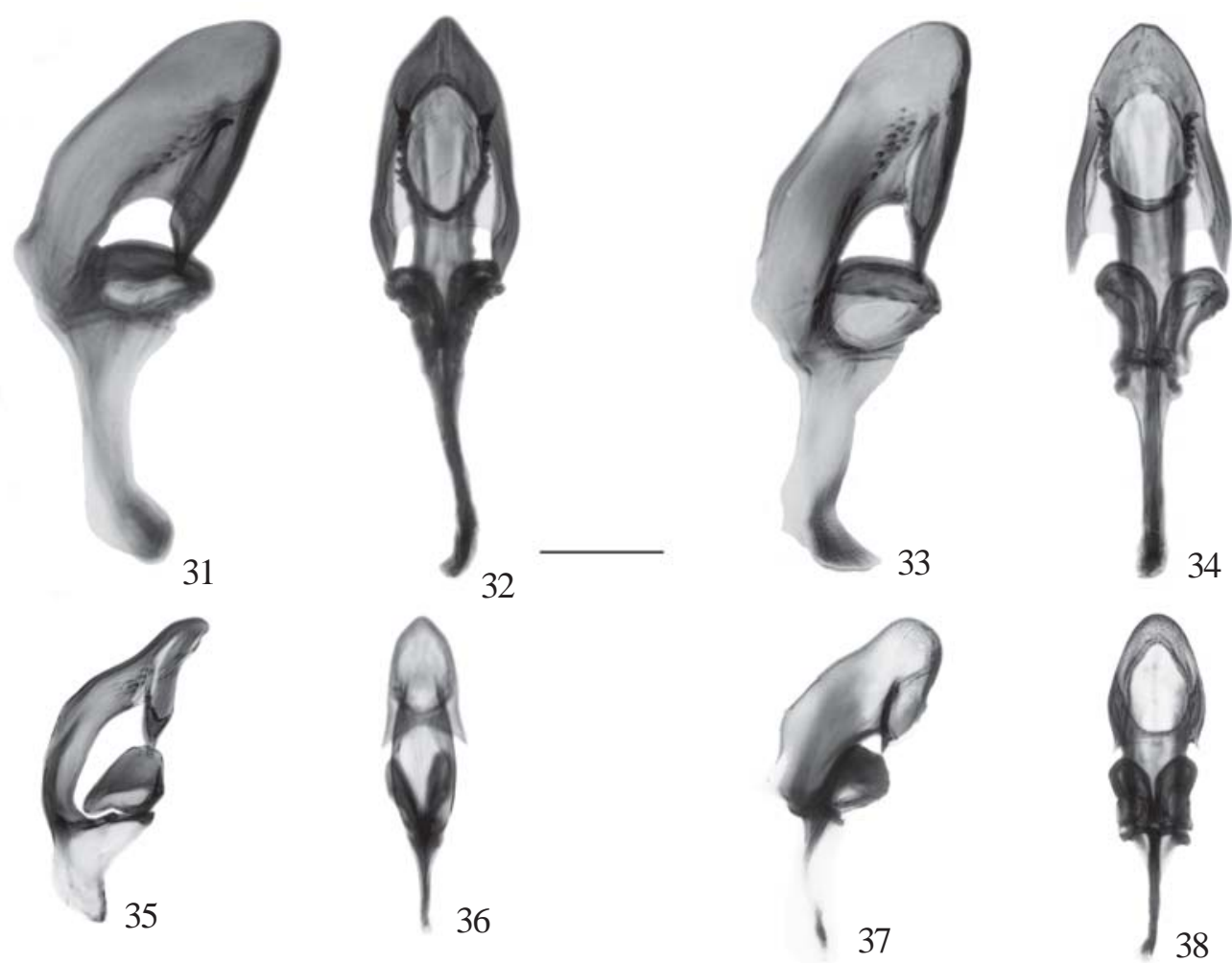

Figs. 31 -38. Photomicrographies of left lateral view and dorsal view of aedeagus+aedeagal apodeme and paraphyses of : 31, 32. Drosophila pauliceia sp. nov., paratype; 33, 34, idem, holotype; 35, 36, Drosophila atalaia, paratype from Vitória (ES); 37, 38, Drosophila boraceia, holotype. Scale bar $=0.1 \mathrm{~mm}$.

distinct from those of the latter. In fact, the oviscapt valves with the distalmost discal setae longer than preceding ones and the weakly sclerotized inner capsules of spermathecae of Drosophila peruensis are more similar to those of Drosophila pauliceia sp. nov. than they are to those of the species of the guarani group. For this reason we are proposing the transference of Drosophila peruensis from the guarani group to a new group named peruensis. The eventual discovery of the male of the latter species will show whether this transference is justified.

Although Vilela \& Val (2004:46) pointed out the morphological similarities between Drosophila boraceia (Figs. 37,38 ) and the also spot-thoraxed Drosophila atalaia (Figs. $20-30,35,36)$ they did not took any decision regarding grouping them. However, even though they mostly inhabit partially adjacent contrasting biomes, i.e., the wet Atlantic Forest and some patches of cacti growing in the dry rocky coast respectively, we currently believe that, besides the morphological similarities, they are closely related species. So far, is seems to be clear that the triad of forest-dwelling species, namely $D$. boraceia, $D$. pauliceia, sp. nov, and $D$. peruensis are more closely related to each other than they are to the xerophilous and probably cactophilic $D$. atalaia. A similar situation of related species of Drosophila living in contrasting biomes is known to occur with most species belonging to two subgroups (namely fasciola subgroup and mulleri subgroup) of the primarily cactophilic Drosophila repleta species group.
We believe Drosophila pauliceia, sp. nov. , as it seems to be the case for Drosophila boraceia, is probably not attracted to fruit-baited traps, where it has been only accidentally collected. The same may be true for Drosophila peruensis, because in an attempt made by one of us (CRV) to collect a male of this species in its putative type locality using two open banana-baited traps set alongside the Urubamba River (one trap near the right and the other near the left margin), on 1-2.II.1984, not even a single specimen belonging to this species was captured. However, it should be pointed out that 20 specimens ( 7 males : 13 females) belonging to Drosophila urubamba, then misidentified (Vilela \& Pereira, 1985) as $D$. peruensis, out of a total of 55 Drosophila ssp. specimens were collected (unpublished data) at that time in those two traps. In contrast, Drosophila atalaia was collected by one of us (CRV) and Visut Baimai in reasonable numbers (68 out of 2,977 specimens of Drosophila spp. sampled ) in such baits at Arraial do Cabo, state of Rio de Janeiro, Brazil (type locality) on 25-26.X.1981 (unpublished data).

Regarding the male terminalia, Vilela \& Sene (1982:345) pointed out an additional similarity, and a probable close relationship, between Drosophila atalaia and Drosophila caponei Pavan \& Cunha, 1947. Later on, Vilela \& Bächli (1990:115, 267 [Fig. 110]) compared the male terminalia of both species with those of Drosophila neochracea Wheeler, 1959 and considered the three species as probably related. Taking into account that the latter two species seems to be closely 
related to each other, but not so close to Drosophila atalaia, as previously pointed out by one of us (Vilela 2001:341), we opted to propose another new group, named caponei group, to include them. The two new groups are diagnosed below.

\section{Drosophila peruensis species group (new group)}

Species included (4). Drosophila atalaia Vilela \& Sene, 1982, D. boraceia Vilela \& Val, 2004, D. pauliceia sp. nov. and D. peruensis Wheeler, 1959.

Diagnosis. Small flies, with most setae and setulae of the thorax and head arising from dark brown spots, which may be somewhat fused; wings with both main crossveins slightly or strongly darker than longitudinal ones, except in D. atalaia; surstylus mostly microtrichose; hypandrium somewhat square-shaped, mostly fused to gonopods and devoid of dorsal arch, which is spurious in D. atalaia; aedeagus stout, bearing a pair of ventral, subapical spurs; paraphysis somewhat square-shaped. Oviscapt bearing both peg-shaped and trichoid-shaped ovisensilla, the distalmost discal one being longer than proximal ones, except in $D$. atalaia.

Comment. The undetermined and probably undescribed Drosophila sp. 1 of Vilela \& Cunha (2006: 585,586), collected in Angra dos Reis (state of Rio de Janeiro) and illustrated by Marta E. Breuer, may prove to belong to this group, even though its aedeagus is devoid of a ventral pair of subapical spurs. The overall aspect of the epandrium and surstyli, the presence of thorax setae arising from dark spots, and the shadows on the main wing crossveins (as stated on Marta Breuer's sketchbook) recall the species included in the peruensis group.

\section{Drosophila caponei species group, new group}

Species included (2). D. caponei Pavan \& Cunha, 1947 and D. neochracea Wheeler, 1959.

Diagnosis (based on the original descriptions, and redescriptions). Thorax devoid of spots; wings hyaline; epandrium bearing a conspicuously ribbon-shaped ventral lobe; surstylus partially membranous, devoid of microtrichia, and bearing sharply pointed prensisetae; aedeagus with a pair of ventral, subapical, and remarkably bifid spurs. For detailed illustrations of the male terminalia of $D$. caponei refer to Val (1982:344 [figs 23a-e]) and Vilela (2001:342 [figs. 1-8]) and of $D$. neochracea see Vilela \& Bächli (1990:267 [fig. 110A-H], 318 [fig. 161k]).
Acknowledgments. We are indebted to Dr. Denise S. Sheepmaker (IB-USP) for allowing the use of her photomicrography equipment and two anonymous referees for corrections and useful suggestions that improved the submitted version.

\section{REFERENCES}

Bächli, G; C. R. Vilela; S. A. Escher \& A. Saura. 2004. The Drosophilidae (Diptera) of Fennoscandia and Denmark. Fauna Entomologica Scandinavica, v. 39. Leiden, Brill, 362 p.

Sturtevant, A. H. 1942. The classification of the genus Drosophila, with descriptions of nine new species. University of Texas Publications 4213: 5-51.

Val, F. C. do. 1982. The male genitalia of some Neotropical Drosophila: notes and illustrations. Papéis Avulsos de Zoologia 34: 309347.

Vilela, C. R. 1983. A revision of the Drosophila repleta species group (Diptera, Drosophilidae). Revista Brasileira de Entomologia 27: $1-114$.

Vilela, C. R. 2001. Breeding sites of Neotropical Drosophilidae (Diptera).III. Rotting infructescences of Philodendron bipinnatifidum (Araceae). Revista Brasileira de Entomologia 45: 339-344.

Vilela, C. R. \& G. Bächli. 1990. Taxonomic studies on neotropical species of seven genera of Drosophilidae (Diptera). Mitteilungen der schweizerischen Entomologischen Gesellschaft 63: 1332 .

Vilela, C. R. \& G. Bächli. 2000. Morphological and ecological notes on the two species of Drosophila belonging to the subgenus Siphlodora Patterson \& Mainland, 1944 (Diptera, Drosophilidae). Mitteilungen der schweizerischen Entomologischen Gesellschaft 73: 23-47.

Vilela, C. R. \& A. B. da Cunha. 2006. On Marta Breuer and some of her unpublished drawings of Drosophila spp. male terminalia (Diptera, Drosophilidae). Genetics and Molecular Biology 29: 580-587.

Vilela, C. R. \& M. A. Q. R. Pereira. 1985. Notes on two species of spotthoraxed Drosophila belonging to the guarani group (Diptera, Drosophilidae). Revista Brasileira de Entomologia 29: 435442.

Vilela, C. R. \& M. A. Q. R. Pereira. 1993. A case of misidentification of a Neotropical species of Drosophila (Diptera, Drosophilidae) belonging to the guarani group. Revista Brasileira de Entomologia 37: 819-820.

Vilela, C. R. \& F. M. Sene. 1982. A new spotted thorax species of the genus Drosophila (Diptera, Drosophilidae). Revista Brasileira de Entomologia 26: 343-347.

Vilela, C. R. \& F. C. Val. 2004. A new spot-thoraxed species of Drosophila from the Atlantic Forest of southeastern Brazil (Diptera, Drosophilidae). Revista Brasileira de Entomologia 48: 45-48.

Vilela, C. R.; F. M. Sene \& M. A. Q. R. Pereira. 1980. On the Drosophila fauna of Chaco and east slopes of the Andes in Argentina. Revista Brasileira de Biologia 40: $837-841$. 